\title{
PROFIL KEMAMPUAN BERPIKIR KREATIF SISWA SEKOLAH MENENGAH PERTAMA DITINJAU DARI TINGKAT KECEMASAN MATEMATIKA DAN JENDER
}

\author{
Disti Pratiwi \\ Endang Wahyuningrum \\ Sandra Sukmaning Adji \\ Program Pascasarjana Universitas Terbuka \\ e-mail: disti.pratiwi22@gmail.com
}

\begin{abstract}
The purpose of this study was to describe the creative thinking skills of junior high school students based on mathematics anxiety and gender. Aspects of creative thinking skills used in this study are fluency, flexibility, and novelty. This research is a qualitative descriptive study. The instruments used were open-ended questions consisting of algebra and geometry questions, mathematics anxiety questionnaires, and interview guidelines. The study was conducted in class IX E of SMPI Al Azhar 12 Rawamangun Jakarta. The subject of this study consisted of four students, they are male student with low mathematics anxiety, female student with low mathematics anxiety, male student with medium mathematics anxiety, and female student with medium mathematics anxiety. The results of the mathematics anxiety questionnaire showed that none of the students in class IX E had high math anxiety. There are differences in the fulfillment of aspects of creative thinking in terms of differences in mathematics anxiety and gender levels. Students with low math anxiety fulfill aspects of fluency, flexibility, and novelty in algebra and geometry questions. Students with medium math anxiety fulfill aspects of fluency and flexibility both in algebra and geometry questions. Female students fulfill aspects of fluency, flexibility, and novelty both in algebra and geometry questions. Male students fulfill aspects of fluency and flexibility in algebra questions, while in geometry questions the aspects that are fulfilled are fluency, flexibility, and novelty.
\end{abstract}

Keywords: Creative thinking skill, open-ended, mathematics anxiety, gender.

\section{PENDAHULUAN}

Seseorang memerlukan kemampuan berpikir kreatif untuk menyelesaikan suatu masalah. Siswono (2006) mendefinisikan berpikir kreatif sebagai suatu proses yang digunakan ketika kita mendatangkan atau memunculkan suatu ide baru. Alexander (2007) berpendapat bahwa kesuksesan hidup manusia ditentukan oleh kemampuannya untuk secara kreatif menyelesaikan masalah, baik dalam skala besar maupun kecil. Namun, kemampuan berpikir kreatif di Indonesia saat ini masih belum memuaskan. Hasil TIMSS (Trends in Mathematics and Science Study) pada tahun 2011 menunjukkan Indonesia berada pada urutan ke-38 dengan skor 386 dari 42 negara peserta. Pemerintah telah berupaya untuk terus meningkatkan kemampuan berpikir kreatif siswa di Indonesia. Salah satu upaya yang dilakukan adalah menggunakan soal kategori HOTS dalam UNBK (Ujian Nasional Berbasis Komputer) agar siswa semakin kreatif dan kritis. 
Berbekal hasil TIMSS dan rencana pemerintah untuk terus menggunakan soal kategori HOTS pada UNBK, guru memiliki peranan penting untuk terus mengembangkan kemampuan berpikir kreatif siswa. Salah satu upaya yang dapat dilakukan adalah merancang model pembelajaran yang tepat. Sebuah model pembelajaran dapat sesuai dengan seorang siswa, namun tidak sesuai dengan siswa yang lain. Oleh karena itu, mengamati karakter-karakter siswa yang dapat memengaruhi kemampuan berpikir kreatifnya menjadi langkah awal yang baik dalam merencanakan model pembelajaran yang sesuai untuk mengembangkan kemampuan berpikir kreatif.

Gangguan yang dapat menyerang siswa saat terlibat dalam pembelajaran matematika dan memengaruhi kemampuan berpikirnya adalah kecemasan matematika. Machromah, Riyadi, dan Usodo (2015) mengatakan bahwa kecemasan matematika yang dialami siswa akan mengganggu proses berpikir siswa. Selain kecemasan matematika, gender juga memengaruhi kreativitas siswa. Menurut Subarinah (2013) gender merupakan jenis kelamin bawaan lahir yang dipengaruhi oleh faktor sosial dan budaya. Penelitian yang dilakukan oleh Dilla, Hidayat, dan Rohaeti (2018) menyatakan bahwa terdapat pengaruh perbedaan gender terhadap hasil pencapaian kemampuan berpikir kreatif matematis siswa.

Salah satu cara untuk meningkatkan kemampuan berpikir kreatif siswa adalah melatih siswa menyelesaikan soal terbuka (open-ended). Menurut Hashimoto (1997) jenis masalah yang mempunyai potensi untuk mengembangkan kemampuan berpikir kreatif siswa adalah masalah atau soal terbuka (open-ended). Soal open-ended adalah soal yang mempunyai lebih dari satu cara penyelesaian. Mahmudi (2008b) menyatakan bahwa soal open-ended memicu siswa untuk secara kreatif mengeksplorasi berbagai cara atau solusi dari masalah tersebut.

Dengan adanya informasi bahwa kecemasan matematika dan perbedaan gender dapat memengaruhi cara berpikir seperti yang telah diuraikan sebelumnya, maka peneliti tertarik untuk melakukan penelitian mengenai profil kemampuan berpikir kreatif siswa SMP ditinjau dari tingkat kecemasan dan gender. Penelitian ini bertujuan untuk: (1) mendeskripsikan profil kemampuan kemampuan berpikir kreatif siswa SMP ditinjau dari tingkat kecemasan matematika dalam menyelesaikan soal open-ended, (2) mendeskripsikan profil kemampuan kemampuan berpikir kreatif siswa SMP ditinjau dari gender dalam menyelesaikan soal open-ended.

Hasil penelitian dapat digunakan sebagai gambaran mengenai kemampuan berpikir kreatif yang dimiliki siswa dan dijadikan pertimbangan dalam penyusunan model pembelajaran yang sesuai agar guru dapat mengembangkan kemampuan berpikir kreatif siswa. Instrumen yang digunakan yaitu soal open-ended. Penelitian dilakukan pada siswa kelas IX E SMP Islam AI Azhar 12 Jakarta dengan pertimbangan bahwa kelas IX E merupakan kelas unggulan dengan nilai rata-rata rapor tertinggi dan memiliki kemampuan matematika yang baik. 
Disti Pratiwi, Endang Wahyuningrum, \& Sandra Sukmaning Adji Profil Kemampuan Berpikir Kreatif Siswa Sekolah Menengah Pertama Ditinjau dari Tingkat Kecemasan Matematika dan Jender

\section{Kajian Literatur dan Teori}

Siswono (2006) mendefinisikan berpikir kreatif sebagai suatu proses yang digunakan ketika kita mendatangkan atau memunculkan suatu ide baru. Selain itu, Evans (1991) juga mendefinisikan berpikir kreatif sebagai suatu aktivitas mental untuk membuat hubungan-hubungan yang terus menerus, sehingga ditemukan kombinasi yang "benar" atau sampai seseorang itu menyerah. Sedangkan Pehkonen (1997) memandang berpikir kreatif sebagai suatu kombinasi dari berpikir logis dan berpikir divergen yang didasarkan pada intuisi tetapi masih dalam kesadaran. Silver (1997) mengatakan bahwa untuk mengukur berpikir kreatif anak-anak dan orang dewasa sering digunakan TTCT (The Torrance Test of Creative Thinking). Tiga komponen yang dinilai dalam kreativitas menurut TTCT adalah kefasihan (fluency), fleksibilitas (flexibility), dan kebaruan (originality). Munandar (2009), merinci ciri-ciri ketiga komponen berpikir kreatif sebagai proses berikut. Ciri-ciri keterampilan fluency adalah: (1) menghasilkan banyak gagasan/jawaban yang relevan; (2) menghasilkan motivasi belajar; (3) arus pemikiran lancar. Ciri-ciri flexibility di antaranya adalah: (1) menghasilkan gagasan-gagasan yang seragam; (2) mampu mengubah cara atau pendekatan; (3) arah pemikiran yang berbeda. Ciri-ciri originality di antaranya adalah: (1) memberikan jawaban yang tidak lazim; (2) memberikan jawaban yang lain daripada yang lain; (3) memberikan jawaban yang jarang diberikan kebanyakan orang.

Nohda (2008) menyatakan bahwa salah satu upaya untuk mendorong aktivitas kreatif siswa dalam memecahkan masalah adalah pemberian soal terbuka (openended) dalam pembelajaran matematika. Takahashi (2008) menjelaskan bahwa soal open-ended adalah soal yang mempunyai banyak solusi atau strategi penyelesaian. Mahmudi (2008a) mengatakan bahwa penggunaan soal open-ended dapat memicu tumbuhnya kemampuan berpikir kreatif. Takahashi (2008) menjelaskan bahwa terdapat beberapa manfaat dari penggunaan soal terbuka dalam pembelajaran matematika, yaitu: (1) siswa menjadi lebih aktif dalam mengekspresikan ide-ide mereka; (2) siswa mempunyai kesempatan lebih untuk secara komprehensif menggunakan pengetahuan dan keterampilan mereka; (3) siswa mempunyai pengalaman yang kaya dalam proses menemukan dan menerima persetujuan dari siswa lain terhadap ide-ide mereka.

Gangguan yang dapat menyerang siswa saat terlibat dalam pembelajaran matematika dan memengaruhi kemampuan berpikirnya adalah kecemasan matematika. Menurut Ashcraft (2002), kecemasan matematika umumnya didefinisikan sebagai perasaan tegang, cemas, atau takut yang mengganggu kinerja matematika. Machromah, Riyadi, dan Usodo (2015) mengatakan bahwa kecemasan matematika yang dialami siswa akan mengganggu proses berpikir siswa. Dzulfikar (2013) menjelaskan bahwa kecemasan dengan intensitas yang wajar dapat dianggap memiliki nilai positif sebagai motivasi. Tetapi, jika instensitasnya berlebih dan bersifat negatif, maka akan menimbulkan kerugian dan mengganggu keadaan fisik maupun psikis seseorang. Cavanagh dan Sparrow (2010) membagi kecemasan matematika menjadi tiga tingkat yaitu kecemasan matematika tinggi, kecemasan matematika sedang, dan kecemasan matematika rendah. 
Selain kecemasan matematika, gender juga merupakan salah satu faktor yang dapat memengaruhi kemampuan berpikir seseorang. Menurut Amir (2013), gender adalah sifat dan perilaku yang dilekatkan pada laki-laki dan perempuan yang dibentuk secara sosial maupun budaya. Peran gender adalah harapan sosial yang menentukan bagaimana laki-laki dan perempuan seharusnya berpikir, bertindak, dan merasakan. Penelitian yang dilakukan oleh Dilla, Hidayat, dan Rohaeti (2018) menunjukkan bahwa gender dan resiliensi memengaruhi pencapaian kemampuan berpikir kreatif siswa. Cramond et al. (2005) menyatakan bahwa dari berbagai penelitian tentang kreativitas ditemukan adanya hubungan antara perbedaan jenis kelamin dengan tingkat kreativitas baik dalam bentuk kuantitas maupun kualitas. Hasil analisis mereka terhadap jurnal penelitian dari tahun 1958-1998 ditemukan adanya perbedaan baik pada aspek fluency, flexibility, originality, dan elaboration.

\section{METODE}

Penelitian ini merupakan penelitian deskriptif kualitatif. Penelitian ini dilaksanakan pada bulan Juli 2018 di SMP Islam Al Azhar 12 Rawamangun Jakarta. Pemilihan subjek penelitian diawali dengan menetapkan jenjang kelas yang akan diteliti, yaitu kelas IX. Kelas yang terpilih adalah kelas IX E yang merupakan kelas unggulan.

Pengumpulan data dilakukan dengan tes tertulis dan wawancara. Tes tertulis dilakukan dengan memberikan angket kecemasan matematika dan soal open-ended. Wawancara dilakukan guna mengonfirmasi jawaban siswa pada tes tertulis serta menggali kemampuan berpikir kreatif yang tidak terlihat pada jawaban tertulis. Instrumen utama adalah peneliti sendiri, sedangkan instrumen bantu terdiri dari angket kecemasan matematika, soal open-ended, dan pedoman wawancara. Angket kecemasan matematika digunakan untuk mengetahui tingkat kecemasan matematika seluruh siswa kelas IX E berdasarkan ketentuan berikut:

$$
\begin{array}{ll}
\text { Kategori tinggi } & : X \geq(\mu+1 \sigma) \\
\text { Kategori sedang } & :(\mu-1 \sigma) \leq X<(\mu+1 \sigma) \\
\text { Kategori rendah } & : X<(\mu-1 \sigma)
\end{array}
$$

(Azwar, 2012)

dimana:

$$
\begin{aligned}
& \mu=\text { Rerata hipotetik } \\
& \sigma=\text { Deviasi standar hipotetik. }
\end{aligned}
$$

Pada penelitian ini, rerata dan deviasi standar yang dipakai untuk pengelompokkan tingkat kecemasan matematika didapatkan dari alat ukur. Angket kecemasan matematika berisi 23 butir soal dengan 4 opsi yang diskor (1 hingga 4). Berdasarkan informasi ini, didapatkan rerata skor hipotetik skala adalah $\mu=57,5$. Nilai tersebut diperoleh dari nilai tengah skor maksimal yang dapat diraih subjek, yaitu $23 \times 4=92$ dengan skor minimal yang dapat diraih subjek yaitu $23 \times 1=23$. Dari 
informasi ini juga didapatkan rentang hipotetik skor yaitu $92-23=69$ (skor maksimal - skor minimal), sehingga deviasi standar skor skala adalah $69: 6=11.5$.

Berdasarkan informasi di atas, disusunlah kriteria pengelompokkan tingkat kecemasan matematika siswa yang digunakan pada penelitian ini:

$\begin{array}{ll}\text { Kecemasan matematika tinggi } & : X \geq 69 \\ \text { Kecemasan matematika sedang } & : 46 \leq X<69 \\ \text { Kecemasan matematika rendah } & : X<46 .\end{array}$

Seluruh siswa pada kelas IX E diberi tes kecemasan matematika. Hasil angket kecemasan matematika menunjukkan bahwa seluruh siswa pada kelas IX E tidak ada yang memiliki tingkat kecemasan matematika tinggi, sehingga subjek penelitian terdiri dari empat siswa yaitu dua siswa laki-laki dengan kecemasan matematika sedang dan rendah, serta dua siswa perempuan dengan kecemasan matematika sedang dan rendah.

Soal open-ended digunakan untuk mengukur kemampuan berpikir kreatif. Aspek kemampuan berpikir kreatif yang akan dilihat pada penelitian ini adalah kefasihan (fluency), fleksibilitas (flexibility), dan kebaruan (originality), karena menurut Silver, Haylock, dan Balka (sebagaimana dikutip dalam Siswomo, 2006) bahwa matematika menekankan pada tiga indikator, yaitu kelancaran (kefasihan), keluwesan (fleksibilitas), dan orisinalitas (kebaruan). Oleh karena itu, soal open-ended yang digunakan untuk mengukur kemampuan berpikir kreatif harus memenuhi kriteria kemampuan berpikir kreatif yaitu kefasihan, fleksibilitas, dan kebaruan. Soal openended ini terdiri dari satu soal ajabar dan satu soal geometri. Pedoman wawancara digunakan sebagai acuan wawancara guna menggali kemampuan berpikir kreatif siswa.

Teknik keabsahan data yang digunakan dalam penelitian ini adalah triangulasi waktu. Menurut Sugiyono (2017), waktu sering memengaruhi kredibilitas data. Untuk itu dalam rangka pengujian kredibilitas data dapat dilakukan dengan cara melakukan pengecekan dengan wawancara, observasi, atau teknik lain dalam waktu atau situasi yang berbeda. Bila hasil uji menghasilkan data yang berbeda, maka dilakukan secara berulang-ulang hingga ditemukan kepastian datanya. Subjek diberi tes soal open-ended 1 dan dilanjutkan dengan wawancara 1. Subjek juga diberi tes soal open-ended 2 yang dilajutkan dengan wawancara 2 pada waktu yang berbeda, di mana soal open-ended 2 serupa dengan soal open-ended 1. Jika hasil yang didapatkan dari tes soal open-ended 2 menunjukkan karakteristik yang sama dengan hasil tes soal open-ended 1, maka data dikatakan valid. Namun, jika hasil tes soal open-ended 2 menunjukkan karakteristik yang berbeda dengan hasil tes soal open-ended 1, maka seterusnya dilakukan pengulangan tes open-ended dan wawancara hingga data dapat dikatakan valid dan ditarik kesimpulan.

Sugiyono (2017) menyebutkan tiga langkah aktivitas dalam analisis data, yaitu reduksi data, penyajian data, dan penarikan kesimpulan. Mereduksi data berarti merangkum, memilih hal-hal yang pokok, memfokuskan pada hal-hal yang penting, 
Disti Pratiwi, Endang Wahyuningrum, \& Sandra Sukmaning Adji -

Profil Kemampuan Berpikir Kreatif Siswa Sekolah Menengah

Pertama Ditinjau dari Tingkat Kecemasan Matematika dan Jender

dicari tema dan polanya. Setelah data direduksi, maka langkah selanjutnya adalah menyajikan data. Langkah penyajian data yang dilakukan pada penelitian ini adalah mengidentifikasi kemampuan berpikir kreatif siswa sesuai dengan indikator yang telah ditentukan. Data yang ditampilkan lebih ringkas sehingga dapat memudahkan dalam penarikan kesimpulan. Langkah yang terakhir adalah penarikan kesimpulan. Pada tahap ini, ditarik kesimpulan mengenai profil kemampuan berpikir kreatif siswa dalam menyelesaikan soal open-ended berdasarkan data yang dihasilkan dari tahap sebelumnya.

\section{HASIL DAN PEMBAHASAN}

Berikut adalah temuan hasil penelitian:

1. Tingkat kecemasan matematika siswa kelas IX E SMP Islam Al Azhar 12 Rawamangun Jakarta

Hasil angket yang diberikan kepada seluruh siswa kelas IX E SMP Islam Al Azhar 12 Rawamangun Jakarta pada tanggal 24 Juli 2018 menunjukkan bahwa tidak ada satu pun siswa yang memiliki tingkat kecemasan matematika tinggi. Hal ini dapat disebabkan karena kelas IX E SMP Islam Al Azhar 12 Rawamangun Jakarta merupakan kelas unggulan yang terbentuk dari siswa-siswa dengan rata-rata rapor tertinggi. Penelitian yang dilakukan oleh Kusumawati dan Nayazik pada tahun 2017 menunjukkan bahwa pada kelompok siswa prestasi atas, kecemasan matematika memiliki hubungan negatif terhadap prestasi siswa. Hal ini berarti pada kelompok siswa yang berkemampuan matematika tinggi, semakin tinggi prestasi siswa, semakin rendah tingkat kecemasan matematikanya.

2. Profil kemampuan berpikir kreatif dalam menyelesaikan soal open-ended

Subjek laki-laki dengan kecemasan matematika rendah memenuhi aspek kefasihan dan fleksibilitas pada soal aljabar. Subjek memenuhi aspek kefasihan karena dapat menuliskan lebih dari satu jawaban dengan benar. Aspek fleksibilitas terpenuhi karena subjek dapat menggunakan lebih dari satu cara untuk menghasilkan suatu jawaban. Sedangkan pada soal geometri, aspek berpikir kreatif yang terpenuhi adalah kefasihan dan kebaruan. Subjek dapat menggambarkan lebih dari satu jawaban dengan benar serta menghasilkan jawaban unik yang belum pernah diajarkan di sekolah, sehingga subjek dikatakan memenuhi aspek kefasihan dan kebaruan.

Subjek perempuan dengan kecemasan matematika rendah memenuhi ketiga aspek kemampuan berpikir kreatif yaitu kefasihan, fleksibilitas, dan kebaruan, baik pada soal aljabar maupun geometri. Subjek memenuhi aspek kefasihan karena dapat menghasilkan lebih dari satu jawaban dengan benar. Subjek mampu menggunakan lebih dari satu cara untuk menghasilkan suatu jawaban, sehingga dapat dikatakan subjek memenuhi aspek fleksibilitas. Selain itu, subjek memenuhi aspek kebaruan karena subjek dapat menemukan jawaban unik yang belum pernah diajarkan di sekolah dan berbeda dengan subjek penelitian lain.

Subjek laki-laki dengan kecemasan matematika sedang memenuhi aspek kefasihan dan fleksibilitas baik pada soal aljabar maupun geometri. Subjek dapat menuliskan lebih dari satu jawaban dengan benar, sehingga subjek memenuhi aspek 
kefasihan. Subjek juga memenuhi aspek fleksibilitas karena dapat menggunakan lebih dari satu cara untuk menemukan jawaban. Namun, subjek tidak dapat menuliskan jawaban unik yang belum pernah diajarkan di sekolah, sehingga subjek dikatakan tidak memenuhi aspek kebaruan.

Subjek perempuan dengan kecemasan matematika sedang memenuhi aspek kefasihan dan fleksibilitas baik pada soal aljabar maupun geometri. Aspek kefasihan terpenuhi karena subjek dapat menuliskan lebih dari satu jawaban dengan benar. Subjek juga dapat menggunakan lebih dari satu cara untuk menghasilkan suatu jawaban sehingga subjek dikatakan memenuhi aspek fleksibilitas. Namun, subjek tidak memenuhi aspek kebaruan karena subjek tidak dapat mengungkapkan jawaban yang unik.

3. Kemampuan berpikir kreatif dalam menyelesaikan soal open-ended ditinjau dari tingkat kecemasan matematika

Perbandingan keterpenuhan aspek kemampuan berpikir kreatif antara subjek berkecemasan matematika rendah dengan subjek berkecemasan sedang ditunjukkan pada Tabel 1.

Tabel 1. Profil Berpikir Kreatif Ditinjau dari Tingkat Kecemasan Matematika

\begin{tabular}{|c|c|c|c|c|c|c|c|c|}
\hline \multirow{3}{*}{$\begin{array}{l}\text { Aspek Berpikir } \\
\text { Kreatif }\end{array}$} & \multicolumn{8}{|c|}{ Tingkat Kecemasan Matematika } \\
\hline & \multicolumn{4}{|c|}{ Rendah } & \multicolumn{4}{|c|}{ Sedang } \\
\hline & \multicolumn{2}{|c|}{$\begin{array}{l}\text { Soal } \\
\text { Aljabar }\end{array}$} & \multicolumn{2}{|c|}{$\begin{array}{c}\text { Soal } \\
\text { Geometri }\end{array}$} & \multicolumn{2}{|c|}{$\begin{array}{c}\text { Soal } \\
\text { Aljabar }\end{array}$} & \multicolumn{2}{|c|}{$\begin{array}{c}\text { Soal } \\
\text { Geometri }\end{array}$} \\
\hline Kefasihan & $\sqrt{ }$ & $\sqrt{ }$ & $\sqrt{ }$ & $\sqrt{ }$ & $\sqrt{ }$ & $\sqrt{ }$ & $\sqrt{ }$ & $\sqrt{ }$ \\
\hline Fleksibilitas & $\sqrt{ }$ & $\sqrt{ }$ & $x$ & $\sqrt{ }$ & $\sqrt{ }$ & $\sqrt{ }$ & $\sqrt{ }$ & $\sqrt{ }$ \\
\hline Kebaruan & $x$ & $\sqrt{ }$ & $\sqrt{ }$ & $\sqrt{ }$ & $x$ & $x$ & $x$ & $x$ \\
\hline
\end{tabular}

Tabel 1 menunjukkan bahwa pada soal aljabar, terdapat perbedaan keterpenuhan aspek berpikir kreatif antara subjek dengan kecemasan matematika sedang dengan subjek dengan kecemasan matematika rendah. Keempat subjek memenuhi aspek kefasihan dan fleksibilitas berdasarkan indikator yang telah ditetapkan. Namun, hanya subjek perempuan dengan kecemasan matematika rendah yang memenuhi aspek kebaruan.

Pada soal geometri, terlihat perbedaan keterpenuhan aspek berpikir kreatif antara siswa berkecemasan rendah dengan siswa berkecemasan sedang. Perbedaan terlihat pada keterpenuhan aspek kebaruan yang hanya dicapai oleh subjek dengan kecemasan matematika rendah. Selain itu, tiga dari empat subjek penelitian memenuhi aspek fleksibilitas. Salah satu subjek berkecemasan matematika rendah mampu memenuhi ketiga aspek berpikir kreatif, yaitu kefasihan, fleksibilitas, dan kebaruan. Sedangkan kedua subjek dengan kecemasan matematika sedang hanya memenuhi aspek kefasihan dan fleksibilitas. 
Disti Pratiwi, Endang Wahyuningrum, \& Sandra Sukmaning Adji -

Profil Kemampuan Berpikir Kreatif Siswa Sekolah Menengah

Pertama Ditinjau dari Tingkat Kecemasan Matematika dan Jender

Berdasarkan uraian di atas, dapat dilihat bahwa subjek dengan kecemasan matematika rendah memenuhi aspek kemampuan berpikir kreatif lebih banyak daripada subjek dengan kecemasan matematika sedang, baik pada soal aljabar, maupuan soal geometri. Penelitian yang dilakukan oleh Machromah, Riyadi, dan Usodo dengan judul "Analisis Proses dan Tingkat Berpikir Kreatif Siswa SMP dalam Pemecahan Masalah Bentuk Soal Cerita Materi Lingkaran Ditinjau dari Kecemasan Matematika" menunjukkan hasil yang serupa, yaitu: (1) siswa dengan tingkat kecemasan matematika tinggi berada dalam kategori TKBK (Tingkat Kemampuan Berpikir Kreatif) 1 atau kurang kreatif; (2) siswa dengan tingkat kecemasan matematika sedang berada dalam kategori TKBK 1 (kurang kreatif) dan TKBK 2 (cukup kreatif); (3) siswa dengan tingkat kecemasan matematika rendah berada dalam kategori TKBK 2 (cukup kreatif). Penelitian tersebut menunjukkan bahwa semakin rendah tingkat kecemasan matematika siswa, semakin tinggi tingkat kemampuan berpikir kreatifnya.

Hal tersebut juga didukung oleh hasil penelitian Priyani (2013) yang mempunyai kesimpulan bahwa antara kecemasan menghadapi pembelajaran matematika dengan prestasi belajar matematika terdapat hubungan negatif dan signifikan. Hal ini dapat dipahami karena menurut Wicaksono dan Saufi (2013) jika kecemasan yang dialami berlebihan, maka dapat berdampak buruk pada diri mereka karena dapat mengurangi efektivitas usaha yang dilakukan. Dzulfikar (2013) juga menjelaskan bahwa kecemasan dengan intensitas yang wajar dapat dianggap memiliki nilai positif sebagai motivasi. Tetapi, jika instensitasnya berlebih dan bersifat negatif, maka akan menimbulkan kerugian dan mengganggu keadaan fisik maupun psikis seseorang.

Selain itu, gejala psikologi kecemasan matematika seperti yang telah dikemukakan oleh College et al. (sebagaimana dikutip dalam Blazer, 2011), yaitu ketidakmampuan berkonsentrasi dan perasaan yang tidak berdaya, khawatir, dan malu terlihat pada saat subjek penelitian mengerjakan tes open-ended. Subjek dengan tingkat kecemasan sedang terlihat ragu dan khawatir dalam menyelesaikan soal. Subjek terus-menerus bertanya mengenai jawabannya apakah sudah benar atau belum. Lain halnya dengan subjek dengan kecemasan matematika rendah yang dapat mengerjakan soal dengan tenang hingga selesai.

Pencapaian masing-masing aspek berpikir kreatif ditinjau dari tingkat kecemasan matematika dijelaskan sebagai berikut. Pada soal aljabar dan geometri, aspek kefasihan dapat dicapai oleh keempat subjek penelitian, baik subjek dengan kecemasan matematika rendah maupun subjek dengan kecemasan matematika sedang. Selain itu, aspek fleksibilitas dipenuhi pula oleh keempat subjek pada soal aljabar. Namun, pada soal geometri aspek fleksibilitas paling banyak dipenuhi oleh subjek dengan kecemasan matematika sedang. Sedangkan aspek kebaruan hanya dapat dicapai oleh subjek dengan kecemasan matematika rendah, baik pada soal aljabar maupun geometri. Hal ini serupa dengan hasil penelitian yang dilakukan oleh Apriliani dan Suyitno (2016) yang menunjukkan bahwa siswa dengan kecemasan ringan sangat produktif dalam menghasilkan ide jawaban yang bervariasi. Penelitian tersebut juga menunjukkan bahwa $41 \%$ siswa dengan kecemasan ringan dapat 
mencapai aspek kebaruan. Sedangkan persentase pencapaian aspek kebaruan pada siswa yang berada pada tingkat kecemasan sedang, berat, dan panik berturut-turut adalah 32\%, 28\%, dan 10\%. Stuart dan Lairan (2005) juga mengungkapkan bahwa pandangan perseptual seseorang pada level kecemasan ringan meningkat dan cenderung lebih kreatif. Siswa dengan kecemasan matematika ringan dapat memberikan penyelesaian lebih dari satu dan berbeda serta menuliskan penyelesaian dengan caranya sendiri dengan cukup unik dan berbeda pada umumnya.

4. Kemampuan berpikir kreatif dalam menyelesaikan soal open-ended ditinjau dari gender

Perbandingan keterpenuhan aspek kemampuan berpikir kreatif antara siswa laki-laki dengan siswa perempuan ditunjukkan pada Tabel 2.

Tabel 2. Profil Berpikir Kreatif Ditinjau dari Gender

\begin{tabular}{|c|c|c|c|c|c|c|c|c|}
\hline \multirow{3}{*}{$\begin{array}{c}\text { Aspek Berpikir } \\
\text { Kreatif }\end{array}$} & \multicolumn{8}{|c|}{ Gender } \\
\hline & \multicolumn{4}{|c|}{ Laki-laki } & \multicolumn{4}{|c|}{ Perempuan } \\
\hline & \multicolumn{2}{|c|}{$\begin{array}{c}\text { Soal } \\
\text { Aljabar }\end{array}$} & \multicolumn{2}{|c|}{$\begin{array}{c}\text { Soal } \\
\text { Geometri }\end{array}$} & \multicolumn{2}{|c|}{$\begin{array}{c}\text { Soal } \\
\text { Aljabar }\end{array}$} & \multicolumn{2}{|c|}{$\begin{array}{c}\text { Soal } \\
\text { Geometri }\end{array}$} \\
\hline Kefasihan & $\sqrt{ }$ & $\sqrt{ }$ & $\sqrt{ }$ & $\sqrt{ }$ & $\sqrt{ }$ & $\sqrt{ }$ & $\sqrt{ }$ & $\sqrt{ }$ \\
\hline Fleksibilitas & $\sqrt{ }$ & $\sqrt{ }$ & $x$ & $\sqrt{ }$ & $\sqrt{ }$ & $\sqrt{ }$ & $\sqrt{ }$ & $\sqrt{ }$ \\
\hline Kebaruan & $x$ & $x$ & $\sqrt{ }$ & $x$ & $\sqrt{ }$ & $x$ & $\sqrt{ }$ & $x$ \\
\hline
\end{tabular}

Tabel 2 menunjukkan bahwa pada soal aljabar, perbedaan kemampuan berpikir kreatif antara subjek penelitian laki-laki dengan subjek penelitian perempuan terlihat pada aspek kebaruan. Keempat subjek memenuhi aspek kefasihan dan fleksibilitas. Namun, hanya satu subjek yang memenuhi aspek kebaruan yaitu subjek perempuan dengan kecemasan matematika rendah.

Pada soal geometri, terlihat bahwa terdapat perbedaan keterpenuhan aspek berpikir kreatif antara siswa laki-laki dengan siswa perempuan. Satu subjek laki-laki tidak memenuhi aspek fleksibilitas. Terdapat satu subjek perempuan yang memenuhi ketiga aspek berpikir kreatif, yaitu kefasihan, fleksibilitas, dan kebaruan. Sedangkan kedua subjek laki-laki hanya memenuhi dua aspek kemampuan berpikir kreatif.

Berdasarkan uraian di atas, dapat dikatakan bahwa subjek penelitian perempuan memenuhi aspek kemampuan berpikir kreatif yang lebih banyak daripada subjek laki-laki. Adanya perbedaan ketercapaian aspek kemampuan berpikir kreatif ini didukung oleh penelitian yang dilakukan oleh Dilla, Hidayat, dan Rohaeti pada tahun 2018 yang menyimpulkan bahwa pencapaian kemampuan berpikir kreatif siswa dipengaruhi oleh faktor gender dan resiliensi siswa sebesar 86,6\%, sedangkan sisanya dipengaruhi oleh faktor lain. Cramond et al. (2005) juga menyatakan bahwa dari berbagai penelitian tentang kreativitas ditemukan adanya hubungan antara perbedaan jenis kelamin dengan tingkat kreativitas baik dalam bentuk kuantitas maupun kualitas. Hal ini dapat dipahami, karena menurut Amir (2013), perbedaan gender tentu menyebabkan perbedaan fisiologi dan memengaruhi psikologis dalam belajar. 
Sehingga siswa laki-laki dan perempuan tentu memiliki banyak perbedaan dalam mempelajari matematika.

Pencapaian masing-masing aspek berpikir kreatif ditinjau dari gender dijelaskan sebagai berikut. Pada soal aljabar dan geometri, baik subjek laki-laki maupun subjek perempuan, mampu memenuhi aspek kefasihan. Selain itu, aspek fleksibilitas dipenuhi pula oleh keempat subjek pada soal aljabar. Namun, pada soal geometri aspek fleksibilitas paling banyak dipenuhi oleh subjek perempuan. Aspek kebaruan tertinggi dicapai oleh subjek perempuan pada soal aljabar. Sedangkan untuk soal geometri, aspek kebaruan dapat dicapai oleh satu subjek laki-laki dan satu subjek perempuan. Hal ini serupa dengan hasil penelitian yang dilakukan oleh Febryana (2018) yang menunjukkan bahwa siswa perempuan memenuhi aspek berpikir kreatif yang lebih banyak dibandingkan dengan siswa laki-laki. Bahkan, salah satu dari tiga subjek perempuan mampu memenuhi ketiga aspek berpikir kreatif, yaitu kefasihan, kebaruan, dan fleksibilitas. Hanya terdapat satu subjek laki-laki yang mencapai aspek fleksibilitas, di mana kedua subjek laki-laki lainnya tidak memenuhi ketiga aspek berpikir kreatif. Bart et al. (2015) melaporkan ada perbedaan yang signifikan bahwa siswa perempuan lebih tinggi keterampilan berpikir kreatifnya dibandingkan dengan siswa laki-laki. Bart et al. (2015) menemukan bahwa siswa perempuan kelas VIII memiliki skor yang jauh lebih tinggi daripada siswa laki-laki di tiga bidang kreativitas

kecuali aspek kefasihan. Hal tersebut terlihat pula pada penelitian ini yang menunjukkan bahwa aspek kefasihan dapat dicapai oleh seluru subjek, baik subjek lakilaki maupun subjek perempuan.

\section{KESIMPULAN}

Berdasarkan hasil analisis data dan pembahasan yang telah dikemukakan pada bab sebelumnya, maka ditarik kesimpulan sebagai berikut:

1. Profil kemampuan kemampuan berpikir kreatif siswa SMP ditinjau dari tingkat kecemasan matematika dalam menyelesaikan soal open-ended.

Pada soal open-ended aljabar, terdapat perbedaan keterpenuhan aspek berpikir kreatif antara subjek berkecemasan matematika sedang dengan subjek berkecemasan matematika rendah. Subjek dengan kecemasan matematika rendah mampu mencapai ketiga aspek berpikir kreatif yaitu kefasihan, fleksibilitas, dan kebaruan. Sedangkan subjek dengan tingkat kecemasan matematika sedang, mampu memenuhi aspek kefasihan dan fleksibilitas. Dalam menyelesaikan soal geometri, baik subjek dengan kecemasan matematika rendah, maupun subjek dengan kecemasan matematika sedang, dapat memenuhi aspek kefasihan dan fleksibilitas. Namun, hanya subjek dengan kecemasan matematika rendah yang dapat memenuhi aspek kebaruan.

2. Profil kemampuan kemampuan berpikir kreatif siswa SMP ditinjau dari gender dalam menyelesaikan soal open-ended.

Pada soal open-ended aljabar, terdapat perbedaan keterpenuhan aspek berpikir kreatif antara subjek perempuan dengan subjek laki-laki. Subjek perempuan mampu mencapai ketiga aspek berpikir kreatif yaitu kefasihan, fleksibilitas, dan 
kebaruan. Sedangkan subjek laki-laki mampu memenuhi aspek kefasihan dan fleksibilitas. Dalam menyelesaikan soal geometri, baik subjek laki-laki maupun subjek perempuan, dapat memenuhi ketiga aspek berpikir kreatif yaitu kefasihan, fleksibilitas, dan kebaruan.

\section{SARAN}

Berdasarkan hasil penelitian ini, saran yang dapat diberikan yaitu:

1. Sebaiknya guru lebih sering memberi latihan berupa soal open-ended agar dapat melatih siswa mengembangkan kemampuan berpikir kreatifnya.

2. Hendaknya guru dapat memberikan motivasi dan pendampingan terhadap siswa yang memiliki tingkat kecemasan matematika sedang dan yang lebih tinggi, karena siswa cenderung memiliki perasaan takut terhadap matematika yang dapat memengaruhi kemampuan berpikirnya.

3. Bagi siswa, terutama siswa yang pencapaian aspek kemampuan berpikir kreatifnya belum maksimal, hendaknya lebih sering berlatih menggunakan soal open-ended agar kemampuan berpikir kreatifnya dapat meningkat.

4. Bagi peneliti lain, hasil dari penelitian ini dapat digunakan sebagai referensi dalam melakukan penelitian lain, terutama penelitian yang terkait dengan peningkatakan kemampuan berpikir kreatif.

\section{REFERENSI}

Alexander, K. D. (2007). Effects instruction in creative problem sloving on cognition, creativity, and satizfaction among ninth grade students in an introduction to world agricultural science and technology course. Disertasi Doktor Texas Tech University.

Amir MZ, Z. (2013). Perspektif gender dalam pembelajaran matematika. Marwah Jurnal Perempuan, Agama, dan Jender, vol. 12, No. 1, 14-31.

Apriliani, L. R. \& Suyitno, H. (2016). Kemampuan berpikir kreatif matematis berdasarkan kecemasan matematika pada pembelajaran creative problem solving berteknik SCAMPER. Unnes Journal of Mathematics Education Research, vol. 5, No. 2, 131-140.

Ashcraft, M. H. (2002). Math anxiety: personal, educational, and cognitive consequences. Sage Journals: Association for Psychological Science, vol. 11, No. 5, 181-185.

Azwar, S. (2012). Penyusunan Skala Psikologi Edisi 2. Yogyakarta: Pustaka Pelajar.

Bart, W. M., Hokanson, B., Sahin, I., \& Abdelsamea, M. A. (2015). An investigation of the gender differences in creative thinking abilities among $8^{\text {th }}$ and $11^{\text {th }}$ grade students. Elsevier: Thinking Skills and Creativity, vol. 17, 17-24.

Blazer, C. (2011). Strategies for reducing math anxiety. Diambil 10 Mei 2018, dari situs World Wide Web: https://files.eric.ed.gov/fulltext/ED536509.pdf.

Cavanagh, R. \& Sparrow, L. L. (2010). Measuring mathematics anxiety: paper 2 constructing and validating the measure. Prosiding AARE Conference 2010 Making a difference. 28 November 2010. Melbourne: Australian Association for Research in Education Inc. 
Cramond, B., Matthews-Morgan, J., Bandalos, D., \& Zuo, L. (2005). A report on the $40-$ year follow-up of the Torrance Test of Creative Thinking: alive and well in the new millennium. Sage Journals: Gifted Child Quarterly, vol. 49, No. 4, 283-291.

Dilla, S. C., Hidayat, W., \& Rohaeti, E. E. (2018). Faktor gender dan resiliensi dalam pencapaian kemampuan berpikir kreatif matematis siswa SMA. Journal of Medives, vol. 2, No. 1, 129-136.

Dzulfikar, A. (2013). Studi literatur: pembelajaran kooperatif dalam mengatasi kecemasan matematika dan mengembangkan self efficacy matematis siswa. Prosiding Seminar Nasional Matematika dan Pendidikan Matematika. 9 November 2013. Yogyakarta: Universitas Negeri Yogyakarta.

Evans, J. R. (1991). Creative Thinking in the Decision and Management Sciences. University of Cincinnati, College Division, South-Western Publishing Co.

Febryana, D. (2018). Profil kreativitas siswa dalam menyelesaikan soal segitiga dan segiempat ditinjau dari gender. Suska Journal of Mathematics Education, vol. 4, No. 1, 50-58.

Hashimoto, Y. (1997). The methods of fostering creativity through mathematical problem solving. Zentralblatt für Didaktik der Mathematik (ZDM) - The International Journal on Mathematics Education, vol. 29, No. 3, 86-87.

Kusumawati, R. \& Nayazik, A. (2017). Kecemasan matematika siswa SMA berdasarkan gender. Journal of Medives, vol. 1, No. 2, 92-99.

Machromah, I. U., Riyadi, \& Usodo, B. (2015). Analisis proses dan tingkat berpikir kreatif siswa SMP dalam pemecahan masalah bentuk soal cerita materi lingkaran ditinjau dari kecemasan matematika. Jurnal Elektronik Pembelajaran Matematika, vol. 3, No. 6, 613-624.

Mahmudi, A. (2008a). Mengembangkan soal terbuka terbuka (open-ended problem) dalam pembelajaran matematika. Makalah disajikan pada Seminar Nasional Matematika dan Pendidikan Matematika. 28 November 2008. Yogyakarta: Universitas Negeri Yogyakarta.

Mahmudi, A. (2008b). Pemecahan masalah dan berpikir kreatif. Makalah disajikan pada Konferensi Nasional Matematika (KNM) XIV. 24-27 Juli 2008. Yogyakarta: Universitas Negeri Yogyakarta.

Munandar, U. (2009). Pengembangan Kreatifitas Anak Berbakat. Jakarta: Rineka Cipta.

Nohda, N. (2008). A Study of "Open-Approach" Method in School Mathematics Teaching - Focusing on Mathematical Problem Solving Acitivites. Diambil 15 April 2018, dari situs Wolrd Wide Web: https:/www.nku.edu/ sheffield/nohda.html.

Pehkonen, E. (1997). The state-of-art in mathematical creativity. Zentralblatt für Didaktik der Mathematik (ZDM) - The International Journal on Mathematics Education, vol. 29, No. 3, 63-67.

Priyani, Y. (2013). Hubungan antara konsep diri dan kecemasan menghadapi pembelajaran matematika dengan prestasi belajar matematika. Yogyakarta: Skripsi Universitas Negeri Yogyakarta.

Silver, E. A. (1997). Fostering creativity through instruction rich in mathematical problem solving and problem posing. Zentralblatt für Didaktik der Mathematik 
(ZDM) - The International Journal on Mathematics Education, vol 29, №. 3, 7580.

Siswono, T. Y. E. (2006). Desain tugas untuk mengidentifikasi kemampuan berpikir kreatif siswa dalam matematika. Jurnal Pancaran Pendidikan Tahun XIX, No. 63, 495-509.

Stuart, G. W. \& Laira, M. T. (2005). Principles and Practice of Psychiatric Nursing $6^{\text {th }}$ ed. St Louis: Mosby.

Subarinah, S. (2013). Profil berpikir kreatif siswa dalam memecahkan masalah tipe investigasi matematik ditinjau dari perbedaan gender. Prosiding Seminar Nasional Matematika dan Pendidikan Matematika. 9 November 2013. Yogyakarta: Universitas Negeri Yogyakarta.

Sugiyono. (2017). Metode Penelitian Kuantitatif, Kualitatif, dan R\&D. Bandung: Alfabeta.

Takahashi, A. (2008). Communication as Process for Students to Learn Mathematical. Diambil 15 April 2018 dari situs Wolrd Wide Web:

http://www.criced.tsukuba.ac.jp/math/apec/apec2008/papers/PDF/14.Akihiko_Takahash i_USA.pdf.

Wicaksono, A. B. \& Saufi, M. (2013). Mengelola kecemasan siswa dalam pembelajaran matematika. Prosiding Seminar Nasional Matematika dan Pendidikan Matematika. 9 November 2013. Yogyakarta: Universitas Negeri Yogyakarta. 